\title{
Das especulações "etimológicas” antigas: as contribuições de Platão e Varrão
}

\author{
MATHEUS TREVIZAM \\ IEL-UNICAMP (Doutorando)
}

RESUMO: Neste artigo, apresentamos resumidamente as visões de Platão (Crátilo) e Varrão reatino (De lingua Latina) sobre a etimologia, buscando alcançar as especificidades de seu pensamento sobre o tema. Como se sabe, a etimologia antiga, nascida no âmbito filosófico entre os gregos e latinos, não se pautava pelos mesmos princípios e não se destinava aos mesmos objetivos que esse campo do saber lingüístico assumiu em nossos dias. Assim, buscamos oferecer aqui uma visão não anacrônica da posição dos autores citados, enfatizando a necessidade da mudança de parâmetros para a correta apreciação do significado das investigaf̧ões etimológicas no passado e no presente.

PALAVRAS-CHAVE: etimologia antiga;filosofia; lingüística moderna.

A investigação etimológica, com o sentido geral de busca do significado das palavras em algo como um estágio anterior de seu percurso na evolução das línguas, constituiu um dos aspectos privilegiados pelo pensamento dos antigos no tocante às especulações teóricas que se deram em torno de questões lingüísticas no período. ${ }^{1}$ Ao longo de séculos de abordagem teórica de temas afins à faculdade humana em questão, autores gregos e romanos antigos retornaram com frequêencia e especial interesse ao tratamento do que podemos chamar apenas com ressalvas de "etimologia".

Essa cautela, é preciso esclarecer, relaciona-se à necessidade de diferenciarmos as concepções dos antigos a respeito do que seria tal busca de sentido das palavras daquilo que atualmente entendemos pelo termo "etimologia". Como se sabe, referimo-nos a ele para indicar um procedimento de investigação linguíśstica regido por métodos bem definidos (entre eles, poder-se-ia incluir a observância das leis de mudança fonética que operam na passagem de uma mesma raiz de um estágio a outro de determinada língua ou, em se tratando de um lapso temporal maior, de uma língua àquelas que dela se originaram posterior-

Cf. Robins, 1980, p. 33: "Los tres aspectos principales de los estudios linguísticos que recibieron atención especial entre los primeros hombres de letras fueron la etimología, la fonética (pronunciación) y la gramática. En la primera, a pesar del mucho entusiasmo, se logró poco que fuera de valor (...)." 
mente), ${ }^{2}$ e que tem como objetivo sobretudo a busca das origens de um vocábulo considerado, entendendo por isso os pontos de partida que é possível associar a ele no passado. Tais pontos de partida, observemos, devem guardar com as formas posteriores "parentescos" morfológicos e de sentido objetivamente comprováveis na história das línguas. Assim, uma forma de etimologia popular como a que se verifica em "sombrancelha" (em que muitos falantes de português associam a palavra usada para designar os supercílios à palavra "sombra", julgando que a primeira proviria de algum modo dessa última) não corresponde ao que é possível depreender cientificamente da história de nossa língua e justifica a forma "sobrancelha" como a única correta do ponto-de-vista da norma culta.

$\mathrm{Na}$ antigüidade clássica, dadas as inevitáveis diferenças de pensamento a respeito da natureza da linguagem em relação ao que se dá modernamente, ou mesmo os interesses peculiares ao período no tocante a esse mesmo objeto, observa-se que a prática dita "etimológica" se revestia de sentidos bem distintos, cuja correta apreciação depende de nosso esforço de nos aproximarmos da cultura antiga sem tantas idéias preconcebidas.

Neste breve ensaio, buscaremos apresentar em linhas gerais a questão do significado da investigação etimológica para a antigüidade greco-latina no contexto cultural e de pensamento em que foi efetivamente praticada, sem o impulso de tentar vê-la como a ancestral direta e imperfeita do que se faz neste campo de estudos em nossos dias. É importante ressaltar, a princípio, a inexistência entre os antigos de uma disciplina exatamente coincidente com algo como a lingüística moderna. Como se sabe, o âmbito fundador de toda atividade intelectual coincidiu, no Ocidente, com a filosofia, cujas subdivisões e derivações posteriores resultaram, após longo processo, em disciplinas mais especializadas do tipo da gramática e das ciências naturais. ${ }^{3}$

Portanto, será preciso compreender o que se afirmou entre os antigos a respeito da linguagem tendo em mente sua inserção num contexto mais amplo, de ordem filosófica. Não casualmente, dois dos principais textos antigos em que se dá destaque à questão etimológica mantêm laços estreitos com a filosofia: no diálogo intitulado Crátilo, de autoria de Platão, são-nos apresentados personagens em interação verbal com Sócrates, do que resulta a própria reflexão lingüístico-epistemológica; no De lingua Latina, do afamado autor romano Varrão reatino, por outro lado, são evidentes os elos de ligação entre as etimologias copiosamente tratadas pelo autor e certos pontos-de-vista a respeito da natureza da linguagem que remetem, por exemplo, ao estoicismo.

No Crátilo platônico, tem-se, como se sabe, a interlocução inicial de Sócrates com Hermógenes, seguida de outra em que, uma vez estabelecidos previamente alguns pontos favoráveis à idéia da "naturalidade" da linguagem, passa-se a contrabalançar a discussão

2 Cf. o exemplo seguinte, em que Saussure (Saussure, 1995, p. 170) fundamenta a descrição da forma francesa apresentada a partir da latina, com base em processos que comenta com rigor: "E como se se dissesse que em francês $e$ se tornou $a$ diante de nasal. Em realidade, ocorreu sucessivamente mudança combinatória, nasalização de $e$ por $n$ [cf. latim uentum $\rightarrow$ francês vẽnt $(. .$.$) ]$ e depois mudança espontânea de $e$ em $\tilde{a}$ [cf. vãnt, (...), atualmente vã]."

3 Cf. Robins, op. cit., p. 25: "Desde el siglo VI a. de C. los filósofos de Jonia y de otras partes estudiaron profundamente la astronomía, la física, las matemáticas, la ética y la metafísica y incluyeron el lenguage dentro de sus estudios." 
através do oferecimento de argumentos em prol da tese convencionalista: nessa segunda parte do diálogo (em que Sócrates interage com Crátilo), fazem-se, pois, como que acertos no que já fora dito antes.

O diálogo se inicia com uma discussão inacabada entre Hermógenes (para quem os nomes são dados aos seres por mera convenção entre os homens) e Crátilo (para quem existe uma relação não arbitrária entre as coisas e os nomes que se referem a elas). Sócrates, declarando-se incapaz de decidir-se entre esses posicionamentos (384c), começa a buscar uma resposta através do questionamento inicial de Hermógenes. Nesse trecho do diálogo, são estabelecidos vários princípios que fundamentam em parte o pensamento platônico a respeito da relação entre as palavras e as coisas. Parece-nos, assim, fundamentalmente importante que Sócrates faça com que Hermógenes admita a existência de algo como uma essência permanente e imutável dos seres (386e); neste caso, tem-se a condição necessária para justificar a hipótese de que os nomes podem ser mal ou bem atribuídos. De outro modo (já que nomear bem é adaptar com rigor os nomes à essência dos seres), como encontrar um critério de verificação do grau de acerto dessa operação?

Um outro aspecto de grande importância para a compreensão do posicionamento de Sócrates na primeira parte do diálogo diz respeito ao fato de que, segundo ele, os nomes teriam sido estabelecidos no início por um artesão especializado ou "nomoteta" (389a), que se teria encarregado da tarefa a ele destinada sob a direção de um dialético a fim de que pudesse alcançar com precisão a essência das coisas antes de nomeá-las. Isso significa que a denominação e a própria criação de palavras não devem ser compreendidas nesse contexto como um processo aleatório, que teria ocorrido por determinação de homens quaisquer através do mero acordo entre si, mas enquanto operação cuidadosamente conduzida para o fim específico almejado.

Uma vez determinados esses princípios de validade geral, Sócrates passa a oferecer exemplos do que entende por nomes "bem estabelecidos"; esses exemplos, deve-se dizer, dividem-se em dois grandes blocos cujo teor significativo, como veremos adiante, não é considerado equivalente por certos estudiosos do texto. Há, então, por um lado, a busca etimológica dos sentidos originais de algumas palavras (agrupadas sob rubricas como "nomes de deuses", "nomes de fenômenos naturais", "nomes de astros" e "nomes de noções morais") em outras palavras ou expressões - "nomes derivados" (394b - 421c) - e, por outro, a busca de motivações semânticas na forma de termos apontados como não derivados, isto é, "primitivos" (422a-427d).

No primeiro caso, recorre-se a métodos variados (junção de termos, parafrasagem seguida de ajustes "fonéticos", trocas de fonemas/ letras...) a fim de relacionar as palavras da língua grega escolhidas para exemplificação com outras que supostamente as teriam originado. É o que ocorre quando Sócrates considera nomes como $\sigma a ̈ \mu \alpha$ ("corpo") e 'a $\lambda \eta \theta \varepsilon i ́ \alpha$ ("verdade") como aplicados aos elementos que designam porque respectivamente provenientes de $\sigma \hat{\eta} \mu \alpha$ ("túmulo", sendo o corpo considerado um "túmulo da alma" em algumas escolas filosóficas espiritualistas) e ' $\alpha \lambda \dot{\eta} \theta \varepsilon \hat{\imath} \alpha$ ("trajeto divino").

Quanto aos nomes primitivos, Sócrates, negando-se a recorrer ao "expediente" de atribuir sua origem às línguas bárbaras (e, portanto, a considerar que teriam simplesmente adentrado o grego por "importação"), procura encontrar em elementos segmentais dos mes- 
mos certos nexos entre forma e sentido; a título de exemplificação, o $\rho$, indicador da idéia de movimento, teria sido bem aplicado à formação de uma palavra como peìv ("escorrer"); por sua vez, a idéia de fluidez caracteristicamente associável à letra $\lambda$ encontra-se representada "com acerto" numa palavra como $\lambda \iota \pi \alpha \rho b \nu$ ("untuoso"). Nessa passagem do diálogo, há que se dizer que, embora Sócrates diferencie elementos fônicos como "vogais", "semivogais" e "mudas", não chega a dar tratamento sistemático a todos os fonemas do grego e, portanto, a propor simbolismos para todos os sons da língua.

Quanto à busca etimológica dos sentidos dos termos derivados, indícios de natureza variada parecem indicar que Platão permite que a ironia socrática se manifeste na passagem em que ela surge, de maneira que as afirmações de Sócrates a esse respeito deveriam ser relativizadas e, de preferência, não atribuídas ao autor do texto. ${ }^{4}$ Em erudito estudo interpretativo do Crátilo, V. Goldschmidt (1982, p. 140) ressaltou o caráter "enciclopédico"5 dessa parte da obra, no sentido de que as "etimologias" propostas fazem alusão, entre outras coisas, a teorias de várias escolas filosóficas distintas (como o orfismo e o pitagorismo). Eis, portanto, mais um fator que convida a ter cautela na atribuição das idéias ali expressas a Platão, já que se comprova a origem de muitas delas no âmbito de outras filosofias que não a platônica.

Por sua vez, um estudioso como L. Méridier (Platon, 1931, p. 25), tradutor e comentador do texto grego da edição "Les Belles Lettres" do Crátilo, acredita que a passagem do "simbolismo sonoro" se furtaria ao foco irônico e ao "problema de atribuição" mencionado no parágrafo anterior: ter-se-ia nela um germe da teorização platônica a respeito do naturalismo lingüístico, para o qual o filósofo parece inclinar-se até certo ponto.

Finalmente, se as conclusões tiradas na interlocução com Hermógenes acabam por fazê-lo ceder em sua obstinação de defesa cerrada do convencionalismo linguístico, aquelas a que se chega na segunda parte do diálogo ( $428 \mathrm{~d}$ et sqq.), longe de manifestarem a plena concordância de Sócrates com o "naturalista" Crátilo, fazem, como dissemos, ressalvas à tese correspondente à posição desse último.

Um aspecto fundamental para a compreensão dessa segunda parte diz respeito à possibilidade real, para Sócrates, de que haja nomes mal aplicados às coisas (431e): o nomoteta, argumenta, pode ter fixado mal o entendimento à essência dos seres ao nomear e, com isso, procedido inadequadamente. Por outro lado, mesmo no caso dos nomes "bem aplicados", 0 que se tem em sua relação com as coisas nunca é uma correspondência ponto por ponto com 0 ser, ou seja, totalmente precisa. Nesse sentido é que se pode dizer que o nome, meio representacional, tem uma realidade distinta daquela que nomeia (432d). Isso explica que Sócrates acabe por concluir que, enquanto instrumentos de conhecimento, isto é, de acesso à realidade dos seres, as palavras têm valor limitado; logo, para conhecer as coisas, nada melhor

4 Cf. a esse respeito as esclarecedoras observações de L. Méridier, tradutor e comentador da edição "Les Belles Lettres” ao Crátilo, pp. 15-22.

5 Cf. Goldschmidt, 1982, p. 140: "Avant d'aborder la fin de la deuxième partie, nous voudrions dire un mot sur l'écletisme de l'exposé étymologique. Nous avons essayé, par la comparaison de textes, de montrer combien de théories philosophiques et d'anciennes croyances religieuses étaient mises à contribution dans cette vaste encyclopédie." 
do que buscar o acesso direto a elas mesmas (439b). Como se nota, essa última observação relativiza enormemente o peso da tese naturalista a que Sócrates parecia aquiescer a princípio.

Tais constatações permitem que Sócrates se posicione, no tocante à controvérsia em que se envolvem seus interlocutores no diálogo, de forma moderada, o que significa que, especialmente levando em conta a argumentação desenvolvida ao tratar do simbolismo sonoro dos segmentos fônicos que compõem os nomes primitivos (e, indiretamente, os derivados) e as afirmações posteriores a respeito da boa compreensibilidade de certos termos mal estabelecidos de acordo com os critérios de composição definidos na primeira parte da obra, procura conciliar "naturalidade" e hábito/ convenção no uso lingüístico.

No De lingua Latina de Varrão, é preciso compreender a discussão etimológica (o termo "etimologia" - $\varepsilon \tau \imath \mu \circ \lambda \circ \gamma i \alpha$ - é empregado pelo autor em V, 2) relacionando-a à célebre controvérsia entre analogistas e anomalistas que perpassou toda a discussão "linguística" ao longo de boa parte da antigüidade e é abordada por esse autor. Lyons (1968, p. 4), expondo em linhas gerais o significado dessa controvérsia, inicia suas considerações a respeito dizendo que ela teve suas raízes numa indagação mais ampla e muito freqüente na filosofia grega, relacionada à busca da naturalidade ou convencionalidade de elementos variados da vida em sociedade (e não apenas da linguagem). Por naturalidade, explica, deve-se entender neste caso um modo de existência das coisas por si próprias, independentemente da vontade humana; quanto à convencionalidade, tratar-se-ia de uma característica associável ao que foi estabelecido socialmente pelo acordo entre os homens.

No tocante às discussões que se produziram sob esse enfoque ao longo da antigüidade a respeito de temas propriamente vinculados à linguagem, importa diferenciar, por um lado, a posição dos anomalistas (cujos maiores expoentes foram os filósofos estóicos) e, por outro, a dos analogistas (exemplificados pelos filólogos alexandrinos). No primeiro caso, tinha-se como verdade que a linguagem, a princípio calcada num real de que seria nessa "fase" uma representação fiel, fora lentamente deturpando-se para transformar-se em algo não só distanciado da forma "adequada" que tivera no início mas ainda irregular em seu funcionamento; ${ }^{6}$ quanto a esse último aspecto, o que garantiria a compreensibilidade da linguagem nos estágios mais adiantados de seu desenvolvimento seria a noção do uso, no sentido da constituição de um hábito coletivo de emprego das formas capaz de sobrepujar as dificuldades resultantes das irregularidades da língua.

Um dos mais fortes argumentos utilizado pelos anomalistas para fundamentar suas idéias a respeito da origem "natural" da linguagem diz respeito à existência de palavras de caráter onomatopaico: ao dizer "cocoricó", "tiquetaque", "pipilar" ou algo semelhante, ocorre que buscamos imitar os sons associáveis a esses termos na realidade empírica através de sequiências sonoras integrantes do nível fônico das línguas. Lyons cita (1984, p. 5), além das onomatopéias, outros processos em que se buscou a presença de algum nexo "espontâneo" entre os objetos nomeados e os nomes: trata-se de fatores do tipo da metaforese (a "perna" da cadeira, a "boca" da garrafa, o "bico" do sapato...), da atribuição de motivações aos sons que os compõem (o $\rho$ grego indicando movimento, o $v$ interioridade, o $\lambda$ fluidez...) e de modificações variadas sobre itens vocabulares anteriores

6 Cf. Lyons, 1968, p. 7. 
(supostas derivações por fusão de outros termos, apagamentos e adições - "Deméter" de $\delta \imath \delta \circ v \sigma \alpha \mu \hat{\eta} \tau \varepsilon \rho, \sigma \hat{\omega} \mu \alpha$ de $\sigma \bar{\eta} \mu \alpha$, etc...).

Para os estóicos, especificamente, as palavras primitivas teriam tido sem exceção origem onomatopaica e, dessa produção inicial, ter-se-iam desenvolvido todos os demais itens vocabulares das línguas. ${ }^{7}$ Em contrapartida, os analogistas negavam que tais relações de semelhança entre os objetos do mundo e os nomes usados para representá-los tivessem fundamento na realidade das línguas: elas se estruturariam de modo regular, ditado por regras recuperáveis através da observação acurada de seu funcionamento, e seriam resultantes do acordo social entre os falantes. ${ }^{8}$ M.-A. M. Casquero, prefaciador da edição espanhola do De lingua Latina (Varrón, 1990, p. XXIV), comenta que esses estudiosos, quando remontavam ao passado das palavras e de seus sentidos, faziam-no com intenções de recuperação do que teriam significado antes de serem esquecidas ou deturpadas pelo uso indevido, isto é, desviante dos padrões coincidentes com os de certos autores helênicos adotados como referencial normativo. Nesse período, é bom lembrar, a língua grega falada num grande centro como Alexandria tornara-se um instrumento de comunicação universal, o que significa que, empregada no quotidiano por estrangeiros oriundos de muitas partes da bacia do Mediterrâneo, não correspondia mais a uma variedade castiça do idioma. Os esforços dos analogistas com vistas ao estabelecimento de regras, portanto, têm relação com uma tentativa de preservação da "integridade" da língua diante das modificações que se introduziam nela paulatinamente por essa razão. ${ }^{9}$

Entre os anomalistas, o sentido da prática etimológica era bem diverso: uma vez que num passado remoto os nomes e as coisas já tinham convivido em relação de proximidade, recorrer à busca dos sentidos originais das palavras gregas e latinas significava poder ter acesso a uma forma mais profunda de conhecimento do real:

"É esclarecedor que o estoicismo tenha utilizado o termo 'etimologia', ou seja, 'significado verdadeiro'. De fato, para um estóico, a verdade autêntica de uma palavra consiste na correspondência natural e necessária entre seu significante e seu significado, entre o nome e o objeto designado: bastará desentranhar a origem da palavra para descobrir a essência última do que designa. Essa doutrina, defendida por estóicos como Crisipo (...), foi adotada pela escola gramatical de Pérgamo, liderada por Crates de Malo."'10

\footnotetext{
Cf. Lyons, op. cit., p. 5.

Cf. Lyons, op. cit., p. 6-7.

4 Cf. Lyons, op. cit., p. 9.
}

${ }^{10}$ Cf. Varrón, 1990, p. XXIV. É importante observar aqui que, embora muito influenciado pelo pensamento etimológico estóico, Varrão também incorpora ecleticamente, como observa Casquero, o pragmatismo dos alexandrinos e chega a discordar dos adeptos da Escola do Pórtico dizendo que nem sempre é possível descobrir a origem e o significado primordial de todas as palavras (De lingua Latina V, 5-9). 
Do mesmo modo que se notava no Crátilo platônico, as etimologias elencadas por Varrão nos livros V, VI e VII de sua obra não correspondem, evidentemente, aos critérios de investigação filológica e linguiística atuais: a esse respeito, grassa na obra grande liberdade de método. Citando um exemplo, tem-se para uma palavra como ager ("campo") a seguinte explicação:

Ager dictus in quam terram quid agebant, et unde quid agebant fructus causa; alii, quod id Graeci dicunt óppov."

'Fala-se 'campo' para designar a terra para onde transportavam algo ou de onde transportavam algo em razão da colheita; uns o justificam pelo fato de que os gregos dizem ơpóv."

Como se nota, há uma busca de semelhanças formais entre a palavra que se deseja analisar e seu étimo. Essa busca, no entanto, pauta-se por critérios muito peculiares aos usos que os antigos faziam da investigação etimológica: o étimo, nesse âmbito, deveria usualmente lançar luzes sobre alguma característica "encoberta" do vocábulo considerado. É importante notar a esse respeito que tal característica não tem relação necessária com traços semânticos de fato transmitidos do étimo para o termo derivado (caso da evolução da palavra caballus do latim vulgar para o português "cavalo" e o francês "cheval"), mas sim com associações que se fazem bastante livremente aos olhos modernos com base no que se julgava que o termo derivado poderia conter em si semanticamente. Uma vez estabelecido o parentesco formal entre esses dois pólos de evolução vocabular, o significado do termo considerado primitivo passa a constituir uma explicação para o sentido e a forma do termo dado como dele proveniente.

A segunda alternativa oferecida, que faz a palavra latina ager derivar não de supostos antecedentes vernáculos, mas de um termo grego, baseia-se, evidentemente, num método de explicação diverso, em que se conserva, todavia, a recorrência à busca da proximidade formal entre o étimo e o termo analisado. Curiosamente, como é sabido, a palavra latina ager e a grega óopós são em certo sentido "aparentadas", já que remetem ambas a uma mesma raiz indo-européia. Ocorre, porém, que a relação que se deveria estabelecer entre elas com base nos critérios da atual linguística histórica não coincide com a proposta de Varrão a esse respeito: como é comum em se tratando da etimologia praticada pelos romanos na antiguididade, o desconhecimento do modo de ramificação da família indo-européia (ou sequer de sua existência) levava-os a cometer o que chamaríamos de equívocos, ${ }^{12}$ fazendo com que frequentemente se atribuísse ao grego a origem de palavras latinas de base vernácula ou, num extremo, a origem de todo o latim. ${ }^{13}$ Em que pese a esses "equívocos"

"Cf. Varrón, op. cit., p. 27.

12 Embora os procedimentos de análise etimológica adotados pelos antigos não correspondam, em absoluto, aos nossos, tinham legitimidade no interior daquilo que se propunham fazer a esse respeito. Chamá-los equivocados, portanto, só se justifica quando os observamos com olhos modernos.

${ }^{13}$ Cf. Robins, op, cit., p. 58. 
reais, entretanto, há que se observar que o método de fazer remontar certas formas correntemente utilizadas num dado estágio de uma língua qualquer a outras formas de uma "língua mãe" é reconhecido como válido e praticado também modernamente.

Num autor como Varrão, em cuja obra sobressai a face do erudito conhecedor das tradições de sua pátria, é curioso notar que a etimologia, além do caráter de instrumento para o contato mais apurado com a realidade no sentido propriamente filosófico da questão, assume o papel de elemento esclarecedor de certos fatos vinculados ao passado de Roma. Desse modo, como certos exemplos comprovam, o bom conhecimento das palavras (em seus sentidos "primordiais", ainda não desgastados pelo uso automatizado a que se submeteram quotidianamente) resulta instrutivo para os que o puderem manejar com propriedade:

Tertiae regionis colles quinque ab deorum fanis appellati, e quis nobiles duo. Collis Viminalis a Ioue Viminio, quod ibi ara eius. Sunt qui, quod ibi uimineta fuerint. Collis Quirinalis, quod ibi Quirini fanum. Sunt qui a Quiritibus, qui cum Tatio Curibus uenerunt ad Romam, quod ibi habuerint castra. $^{14}$

"As cinco colinas da terceira região foram denominadas a partir dos templos dos deuses, dentre os quais há dois célebres. A colina Viminal de Júpiter Viminius (do vime), pois seu altar se localiza ali. Há os que o justifiquem porque ali houve vimeirais. A colina Quirinal, porque o templo de Quirino ali se localiza. Há os que o justifiquem com base em Quirites, ${ }^{15}$ porque, quando vieram com Tácio de Cures para Roma, estabeleceram ali seu acampamento."

Uma vez apresentadas as motivações histórico-culturais que se encontram na raiz do interesse de ambos os autores antigos tratados pela questão "etimológica", resta-nos fazer um breve comentário a respeito de certo viés de leitura dos modernos ao se referirem a obras como aquelas de que nos ocupamos aqui. Como tendência geral entre os historiadores da lingüística, nota-se um impulso duplo de vinculação e distanciamento dessa disciplina, tal como entendida em nossos dias, das reflexões que se fizeram na antigüidade sobre aspectos variados da linguagem. ${ }^{16}$

Por um lado, trata-se de buscar na palavra de "grandes vultos" do passado (a exemplo dos próprios Platão e Varrão) um ponto de partida fundador de toda a teorização que se praticou posteriormente no Ocidente a respeito de temas vinculados à linguagem humana.

14 Cf. Varrón, op. cit., p. 39.

15 O termo quirites apresenta, em latim, o significado de "cidadão romano". Desse modo, a etimologia que faz o nome do monte Quirinal derivar dessa palavra alude a um evento da história longínqua de Roma em que os latinos teriam sido liderados em expedição militar por Tácio, rei dos sabinos, e estabelecido base militar na região da colina mencionada.

16 Considere-se, por exemplo, a posição de Robins (op. cit., p. 26) sobre o Crátilo: "Un diálogo, el Crátilo, es consagrado a cuestiones linguísticas, aunque en algunos aspectos de su contenido es decepcionante (grifo nosso)." 
Tais autores, acredita-se, teriam favorecido à sua maneira e já em sua época o nascimento de uma suposta "ciência lingüística". ${ }^{17}$ Em contrapartida, os mesmos que se sentem inclinados a buscar relações especulares entre o antigo e o moderno nesses termos muito freqüentemente apresentam as discussões antigas como "imaturas" e inadequadas, baseando-se para tanto em critérios metodológicos e teóricos característicos de nossa época.

Acreditamos que esses posicionamentos, tão comumente encontrados em convivência nas palavras de certos lingtuistas, não poderiam acomodar-se de forma pacífica caso o impulso bipartido que os condiciona fosse submetido a uma visão menos ingênua. Em verdade, como afirmamos antes, sabemos que a antiguidade não concebeu áreas do conhecimento diretamente identificáveis com o que entendemos em nossos dias por "lingüística" ou mesmo "gramática"18 (no sentido mais corriqueiro do termo).

Por que, então, ao invés de buscar nos antigos aquilo que eles jamais se propuseram ser (em razão da própria impossibilidade de que pudessem antecipar anacronicamente preocupações e interesses concernentes aos modernos), não renunciar à idéia falsa dessa espécie de linearidade "evolutiva" e absoluta do pensamento sobre a linguagem, fator responsável pela produção de tantos equívocos no confronto com o diferente? Como a consulta atenta aos textos originalmente produzidos pelos antigos revela, é de fato impossível obter a identificação imediata das abordagens teóricas a que submeteram certos temas relacionados à linguagem com o que se diz em nossa época a respeito, supostamente, dos mesmos temas.

Portanto, proceder de maneira condizente com essa visão ao tratar de reflexões antigas como aquelas de que nos ocupamos aqui significa desconsiderar a importância decisiva da história para a constituição de quaisquer fenômenos relacionados à cultura humana. Haverá quem, sob o preço de pautar-se por um anacronismo grosseiro, possa eximir-se de considerar a necessidade de um olhar diferenciado para abordagens que, comprovadamente, constituem-se em elementos tão específicos?

\section{Referências Bibliográficas}

GOLDSCHMIDT, V. Essai surle "Cratyle": contribution à l'histoire de la pensée de Platon. Paris: Librairie Philosophique J. Vrin, 1982.

LYONS, J. Introduction to theoretical linguistics. Cambridge: University Press, 1968.

PEREIRA, M. A. Quintiliano gramático: o papel do mestre de gramática na "Institutio oratoria". São Paulo: Humanitas, 2000.

17 O próprio título da obra de Robins citada aqui (em espanhol, Breve historia de la linguística) já pressupõe a compreensão das especulações dos teóricos greco-latinos tratados como ponto inicial de um suposto continuum evolutivo da "ciência lingüística".

18 Cf. a esse respeito as palavras de Pereira (2000, p. 47) sobre o assunto: “A clássica definição do termo 'gramática' remonta justamente a Dionísio Trácio, autor, como vimos, daquele trabalho. Discípulo de Aristarco, um dos principais representantes da chamada 'escola alexandrina', Dionísio definiria sua disciplina como 'o conhecimento prático do uso lingüístico comum aos poetas e prosadores'." 
PLATON. Cratyle. Texte établi et traduit par L. Méridier. Paris: "Les Belles Lettres", 1931.

ROBINS, R. H. Breve historia de la lingüística. Traducido por Enrique Alcaraz Varo. Madrid: Paraninfo, 1980.

de SAUSSURE, F. Curso de lingüistica geral. Tradução de A. Chelini et alii. São Paulo: Cultrix, 1995.

VARRÓN. De lingua Latina. Introducción, traducción y notas de Manuel-Antonio Marcos Casquero. Barcelona: Editorial Anthropos, 1990.

TREVIZAM, Matheus. About the ancient etymological inquiry: the contributions of Plato and Varro. Classica, São Paulo, 15/16, p. 179-188, 2002/2003.

ABSTRACT: In this article, we present briefly the positions of Plato (Cratylus) and Varro of Reate (De lingua Latina) about etymological matters, intending to focus on the particularities of their thought in the theme. As it is known, the ancient etymology, born in philosophical context in the Greek and Roman world, was not determined by the same principies and was not directed to the aims that this area of linguistic knowledge has acquired for us. We try to offer here a nonanachronical view of the positions of the authors mentioned, stressing the need of changing our evaluation patterns for a right comprehension of the meaning of etymological inquiry in past and present days.

KEYWORDS: ancient etymology; philosophy; modern linguistics. 